\title{
PROPOSED BUSINESS PROCESS IMPROVEMENT MODEL WITH INTEGRATED CUSTOMER EXPERIENCE MANAGEMENT
}

\author{
G.J Botha ${ }^{1}$ and A.C. van Rensburg ${ }^{2}$ \\ 1,2Department of Industrial and Systems Engineering \\ University of Pretoria, South Africa \\ ${ }^{1}$ jozine.botha@up.ac.za, ${ }^{2}$ antonie.vanrensburg@up.ac.za
}

\begin{abstract}
In these modern times it is more and more difficult to become and stay competitive in the business environment. Customers have increasingly more products to choose from and more channels through which they can satisfy their needs. In such an environment it is vital to ensure an exceptional customer experience, and to maintain this experience through delivering products and services according to customer needs. This can be achieved by developing a process improvement model that integrates traditional approaches to business process improvement with the concept of customer experience management.
\end{abstract}

\section{OPSOMMING}

In vandag se besigheidsomgewing raak dit al moeiliker om te kompeteer vir die lojaliteit van kliënte. Kliente het al meer produkte om van te kies en heelwat meer kanale waardeur hulle, hulle begeertes kan vervul. In so omgewing is dit baie belangrik om die ervaring van kliënte te verbeter deur produkte en dienste te lewer wat voorsien in al die behoeftes van die kliënt. Dit kan gedoen word deur die ontwikkeling van 'n prosesverbeteringsmodel wat die tradisionele konsep van besigheidsprosesverbetering integreer met kliëntervaring bestuur. 


\section{INTRODUCTION}

The importance of having a customer-focused approach to doing business is emphasised by Blumenthal [2]: "Good customer service is a critical differentiator for organisations and it offers a strategic competitive advantage to those enterprises that embrace it and make it central to their product offering". In a survey done by Bernd Schmitt in 2002, customer focus was identified as the single most important differentiator between the best and worst companies in an industry. Despite this knowledge, many companies still fail to deliver an exceptional experience to the customer. According to Schmitt [15], customers are still being treated as if they didn't matter, or as if they were an afterthought to the companies' really important concerns.

Over the years, marketing departments have used various tools like surveys and mystery shopping to measure customer experience and customer satisfaction. Unfortunately the results of these surveys are rarely integrated with the operations departments' efforts at improvement. According to Meyer et al. [11], few people responsible for the different aspects of a company's offerings have thought about how their separate decisions influence and shape customer experience. Many companies do not see the need to worry about customer experience. Others collect and quantify data on customer experience, but fail to circulate the findings - and those that do circulate them fail to make anyone responsible for making use of the information. Meyer et al. [11] are of the opinion that the first step a company must take to be successful in delivering an exceptional customer experience is to embed the fundamental value proposition into every feature of that company's offerings. Only when companies succeed in designing their processes to deliver products and services according to the needs of the customer, will they be able to enjoy strategic competitive advantage in the form of customer loyalty.

The purpose of this paper is to investigate the development of a process improvement model that integrates traditional approaches to business process improvement with the concept of customer experience management. This investigation will start by exploring the concept of 'customer experience management'.

\section{CUSTOMER EXPERIENCE MANAGEMENT}

\subsection{Customer experience defined}

In the 1970s there was a strong focus on the quality of products and services. This focus shifted in the 1980s to customer satisfaction as the explicit goal of any organisation. According to Gustafsson and Johnson [7], the focus has recently shifted beyond quality and customer satisfaction to focus directly on customer loyalty as the key to profitability. Over the years, organisations have made the mistake of focusing on only one of these concepts at a time, not realising that they are entirely dependent on each other. These concepts represent a system that must be measured and managed as a whole in order to maximise results. Gustafsson and Johnson [7] propose that companies follow a systems approach to customer satisfaction by forming explicit linkages that extend from internal processes to customer perceptions, to customer satisfaction, to loyalty, and ultimately to bottom-line performance. Figure 1 is a framework defined by Gustafsson and Johnson [7]to demonstrate the systems approach they propose. The framework includes four general areas: internal quality, external quality and satisfaction, customer loyalty and retention, and financial performance. Internal quality includes production and maintenance processes. In the case of a service or retailing environment, internal quality includes the service offered, the physical surroundings, and the satisfaction of employees and the resulting service quality they provide [7]. External quality in this framework represents what customers see and feel in the purchase and consumption experience. Loyalty can be seen as the customer's intention or predisposition to buy, while retention is the behaviour itself [7]. Quality, satisfaction, and loyalty ultimately affect financial performance, both directly and indirectly. 


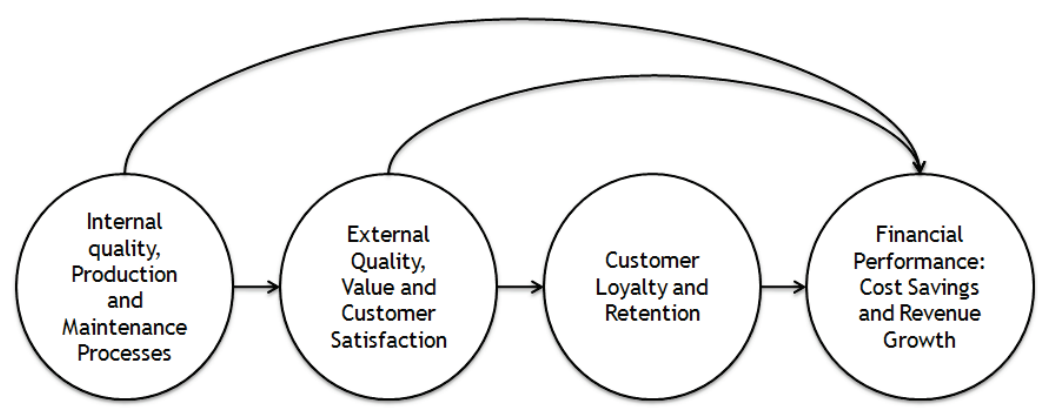

Figure 1: A framework for linking quality to performance (adapted from Gustafsson and Johnson [7])

According to Meyer et al. [11], customer satisfaction is the result of a series of customer experiences, and the net result of good customer experiences minus the bad ones. They define customer experience as "the internal and subjective response customers have to any direct or indirect contact with a company". According to them, customer experience is shaped by every aspect of a company's offering, from direct contact in the customer care department to advertising, packaging, product features, and the use, reliability, and maintainability of the products or services.

\subsection{Customer experience measurement and improvement}

\subsubsection{Improvement through measurement}

Before a company can improve its customer experience, it must understand the current experience delivered to its customers by measuring this experience. This section will discuss what is needed to improve customer experience, and will also address various measurement tools that can be used to measure customer experience.

Meyer et al. [11] are of the opinion that a company can improve its customer experience by creating value for the customer through delivering products and services according to customer needs. According to Payne et al. [12], the value creation process transforms the outputs of the strategy development process into programmes that both extract and deliver value. To determine whether the value proposition specified by the company will indeed result in superior customer experience, a company should undertake a value assessment to quantify the relative importance that customers give to the various attributes of a product or service [12]. According to Gustafsson and Johnson [7], an organisation can assess the value delivered to their customers with an effective customer measurement and management system, as seen in Figure 2 . The system they propose continually pursues three key activities: (1) gather customer information, (2) spread that information throughout the organisation, and (3) use the information to maintain, improve, or innovate in products and processes. According to Meyer et al. [11], information about the customer experience can be collected at 'touch points'. These are instances of direct contact either with the product or service itself, or with a representative of it by the company or some third party. After information on customer needs have been obtained, it can be used to inform the design or improvement of specific business processes. Gustafsson and Johnson [7] propose that companies know how to link their customers' needs with their organisation's processes to create the best possible customer experience. The next section will investigate business process improvement through the linkage between business processes and customer requirements. 


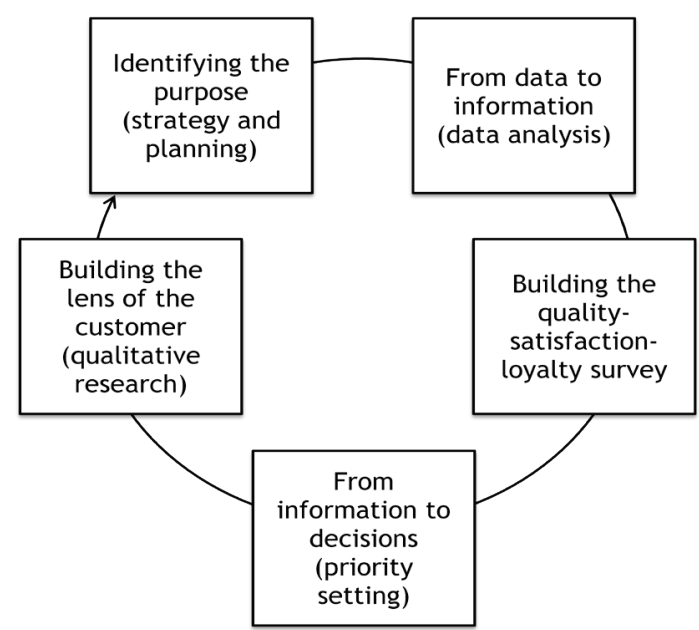

Figure 2: A process model for creating a customer measurement and management system (adapted from Gustafsson and Johnson [7])

\section{BUSINESS PROCESS IMPROVEMENT FROM A CUSTOMER PERSPECTIVE}

\subsection{Business process reengineering as an improvement initiative}

Gladwin and Tumay [6] define business processes as all service processes and processes that support production - for example, order management, engineering changes, and product design. According to them, a business process consists of a group of logically related tasks that use the resources of the organisation to provide defined results in support of the organisation's objectives. From the definition above, it is clear that the business processes of an organisation must be linked to the organisation's objectives or goals, the most important being the goal of customer satisfaction. This link can be obtained by engineering or reengineering business processes to reflect the needs of the customer.

The concept of business process reengineering (BPR) first emerged in 1990 when it was introduced by Michael Hammer [8]. Hammer claimed that the challenge for managers is to obliterate work that does not add value. He states that companies should consider redesigning their business processes in order to maximise customer value. In the same year as Hammer, Davenport and Short [5] published an article on business process redesign that presented a similar idea. They prescribed a five-step approach to business process reengineering:

1. Develop the business vision and process objectives: In this step, it is important to understand the business vision or the objective that drives the reengineering of a specific business process. A typical example would be to improve customer satisfaction.

2. Identify the processes to be redesigned: The most important processes - or the business processes that conflict with the business objective - must be identified. These processes must then be prioritised according to redesign urgency.

3. Understand and measure the existing processes: The current processes must be measured in order to identify areas for improvement and to avoid repeating past mistakes.

4. Identify IT levers: The capability of existing IT systems will have an impact on the ability to redesign business processes.

5. Design and build a prototype of the new process: The new process must be seen as a prototype with consecutive iterations. 
After the appearance of BPR, many authors dedicated their time and effort to researching this new phenomenon. One was Camp [3], who investigated BPR by making use of benchmarking. In his view, there is an intermediate step between identifying business processes and prioritising these processes. The intermediate step that he feels is worth considering is visually to display the linkage to organisational goals on the one hand and the business processes on the other. This picture will help one to understand the direct relationship between business processes and goals. Before this relationship can be established, the most important business processes that impact the goal of customer satisfaction must be identified.

\subsubsection{Identifying key business processes that impact customer satisfaction}

The method suggested by Camp [3] to identify business processes is to create a high level 'helicopter' view of the organisation. This can be done in two ways. The first method involves describing the existing organisation in terms of its functions, and mapping these functions across a flow chart. In the second method, the current organisation is disregarded completely and the logical flow of work is described. This logical flow includes the logical progression of developing and producing products and services and delivering them to customers. A better-known method, which works in much the same way as Camp's second method, is value chain analysis. According to Chase et al. [4], the value chain provides a structure to capture the linkage of organisational activities that create value for the customer and profit for the firm. The value chain can be very useful in identifying all the key business processes needed to deliver value to the customer. These processes include service processes that will have a direct influence on customer experience, as well as support processes (such as employee training, procurement, and stock management) that might have an indirect influence on customer experience. After all the key business processes have been identified, the visual linkage between these processes and customer requirements must be determined.

\subsubsection{Linking business processes to customer requirements}

One of the known methods for linking organisational goals to business processes is the Balanced Scorecard (BSC), introduced by Robert Kaplan and David Norton in 1992 as a performance management tool. According to Chase et al. [4], the Balanced Scorecard facilitates great precision in defining the customer value proposition and the fact that internal business processes, competencies, and technologies must be linked to that value proposition. This value proposition is defined in the customer perspective of the Balanced Scorecard, and represents the measures that the organisation will use to satisfy customer needs. It involves measuring the current value delivered to customers in terms of time, quality, cost, and service, and aligning these metrics to customer requirements in order to increase the value delivered to the customer. According to Kaplan and Norton [9], the internal business process perspective includes all the processes necessary to deliver on the value proposition. From the balanced scorecard or strategy map developed by Kaplan and Norton [9], it is clear that there are many relationships between the internal business process perspective and the customer perspective. These relationships can be seen as a linkage between the goal of customer satisfaction and business processes. The strategy map developed by Kaplan and Norton fails to describe these relationships in sufficient detail, so the opportunity exists to describe them, using different tools in conjunction with the BSC. The tool suggested by Camp [3] for displaying a visual relationship between customer satisfaction and business processes is the tree diagram. Figure 3 shows the tree diagram as designed by Camp [3]. Although the tree diagram is useful in visually displaying the relationships between the customer perspective and the internal business process perspective, the amount of information displayed is limited. The tree diagram only identifies processes that have a relationship with a dissatisfier. It does not display the relationship between all key business processes and organisational goals, but only focuses on processes with low performance. It would thus be useful to investigate alternative methods. This can be done by taking a trip down memory lane to the early 1960s. 


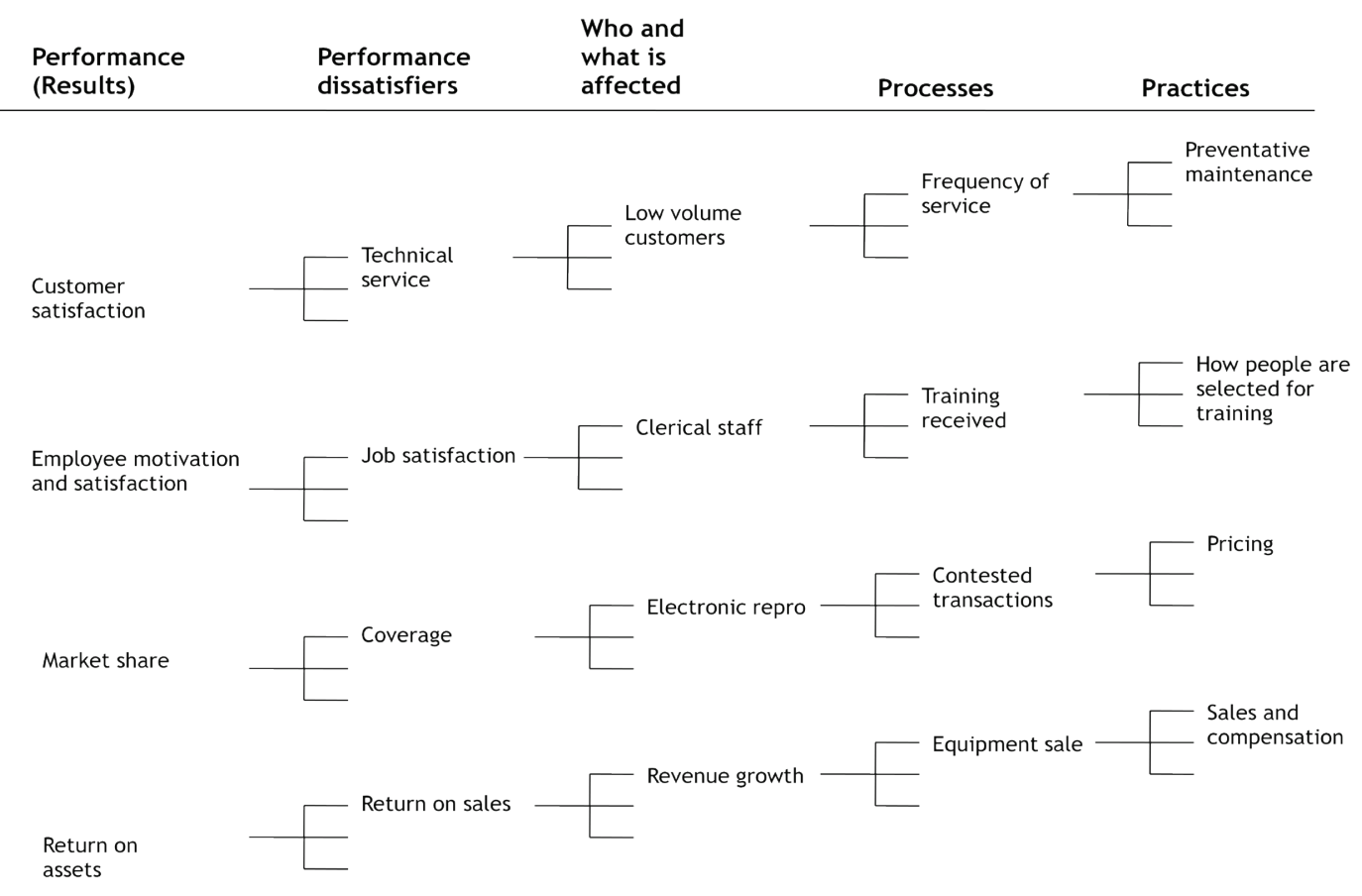

Figure 3: Tree diagram of business processes linked to organisational goals (adapted from Camp [3])

Although the linkage between customer satisfaction and business processes re-emerged in the work of Kaplan and Norton in 1992, it was nothing new. The need to relate the goal of customer satisfaction to business processes originated in the early 1960s when Dr Yoji Akao and Shigeru Mizuno introduced the concept of Quality Function Deployment (QFD). This well-known technique provides the baseline mechanism for achieving the causal relationship between customer requirements, products and services, and business processes. Although QFD is mainly employed to evaluate and improve product characteristics, it can also be used for non-tangible services, including manufactured goods, the service industry, business process development, and many other applications [10]. QFD can easily be used to establish the direct relationship between the customer perspective and the internal business perspective of the BSC by linking customer requirements to business processes. Figure 4 is an example of a generic QFD.

\subsubsection{Prioritising business processes according to their impact and performance}

After the linkage between the customer perspective and the internal business perspective has been obtained, the next step suggested by Camp [3] (and by Davenport and Short [5]) will be to prioritise the business processes. According to Gustafsson and Johnson [7], the areas in the business that can be seen as improvement priorities are those that are important to customers and in which, at the same time, the company is performing poorly. They are of the opinion that managers should identify the priority areas of high importance and low performance. From this prioritisation of service or product attributes, managers can categorise and display the drivers of satisfaction and loyalty, using the strategic satisfaction matrix defined by Gustafsson and Johnson [7]. This matrix was initially defined in order to assist managers in prioritising product and service attributes that need improvement, but it can also be particularly useful in prioritising business processes. The business processes of the company can be divided into four strategic categories, depending on their impact on customer satisfaction as well as their performance. Each category will have a different associated implication for market action. Resources must be focused where 
impact is high and performance is weak. Process improvements within this category will have the greatest impact on customer satisfaction and consequently on loyalty and profitability.

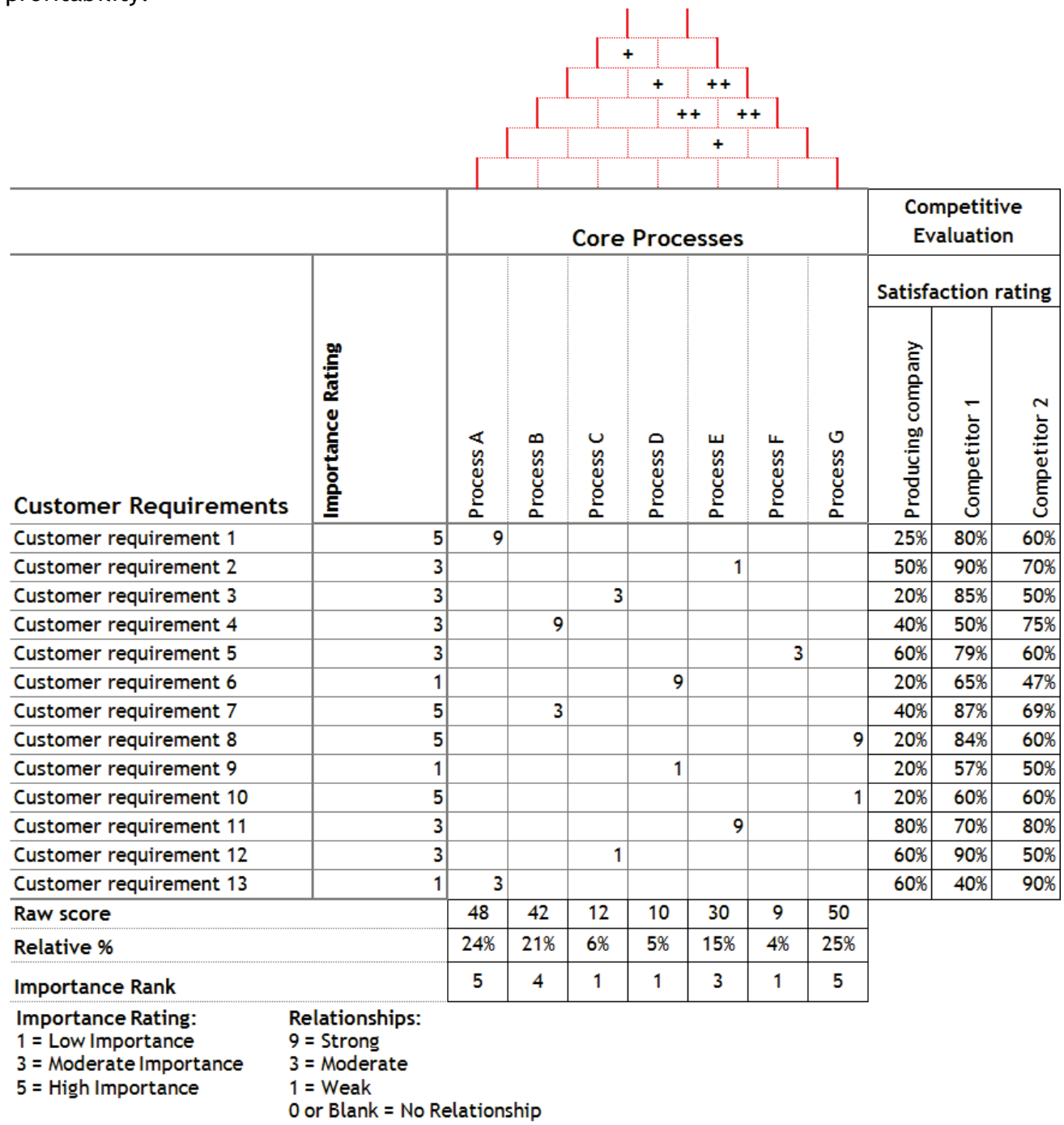

Figure 4: Generic Quality Function Deployment Diagram

\begin{tabular}{|c|c|}
\hline $\begin{array}{c}\text { Low impact and strong } \\
\text { performance } \\
\text { Maintain or reduce } \\
\text { investment or alter target } \\
\text { market }\end{array}$ & $\begin{array}{l}\text { High impact and strong } \\
\text { performance } \\
\text { Maintain or improve } \\
\text { performance - } \\
\text { competitive advantage }\end{array}$ \\
\hline $\begin{array}{l}\text { Low impact and weak } \\
\text { performance } \\
\text { Inconsequential - do not } \\
\text { waste resources }\end{array}$ & $\begin{array}{l}\text { High impact and weak } \\
\text { performance } \\
\text { Focus improvements here } \\
\text { - competitive } \\
\text { vulnerability }\end{array}$ \\
\hline
\end{tabular}

Figure 5: Strategic satisfaction matrix (adapted from Johnson and Gustafsson [7]) 
The impact and performance of a process from a customer perspective can be measured through obtaining and analysing data from the customer. As mentioned in section 2.2.1, data must be obtained about the current experience of the customer to identify areas where the company performs below expectation. The tree diagram identified in the previous section of this paper can be very useful in prioritising business processes according to performance. According to Camp [3], the tree diagram can serve as the base for making line-of-sight decisions on which processes would leverage the goal the most, and thus be the priorities for improvement. As explained earlier, the tree diagram visually displays the relationship between organisational goals and business processes, but it also identifies the areas with which customers are dissatisfied. By developing a tree diagram, a company will be able to identify processes that perform below the expectation of the customer. Customers can then be asked to rank these identified processes according to performance. Although the tree diagram is useful, it can become a very long and complex task. A different method for rating performance that may be simpler and more efficient will be discussed later on.

The tree diagram is useful in identifying processes with low performance, but it cannot be used to prioritise processes based on their impact on the customer. Camp's approach has various shortcomings, such as the lack of information regarding the strength of the relationships or the importance of the dissatisfiers, where dissatisfiers can also be seen as a requirement that has not been met. It is vital to understand the magnitude of the impact a specific process will have on the requirements of relevant stakeholders. This will be determined by the strength of the relationship between the process and the requirements: the stronger the relationship, the higher the impact will be. The importance rating of each requirement, not limited to dissatisfiers, is also vital to obtain, as it will be more important to improve processes that have an impact on customer requirements with high importance from the stakeholder's perspective. In order to prioritise business processes by linking the processes to organisational goals, a tool is needed that can display the relationship together with the strength of the relationship and the importance of each goal. This tool - QFD - was also identified in the previous section. It can be used to relate customer requirements directly to business processes; but by doing this, processes can be prioritised according to their impact on customer requirements. According to Chase et al. [4], the QFD process begins by studying and listening to customers through market research; the consumers' product needs and preferences are defined and broken down into categories called customer requirements. Once customer requirements have been defined through customer surveys and interviews, they are weighted, based on their relative importance to the customer. The next step in the QFD process is to define a set of technical characteristics (which can also refer to business processes) directly related to the customer requirements. Once the QFD diagram has been developed, it will be relatively easy to identify the processes with a high impact on customer requirements. The importance or impact rating for each technical characteristic or process can be seen in the row labeled 'Total score' or 'Current score'; an example of this rating can be seen in Figure 4. The business processes can then be categorized, based on this ranking in the four strategic categories of the strategic satisfaction matrix.

The strategic satisfaction matrix is a primary input into deciding which processes to improve; but according to Gustafsson and Johnson [7], there are also other factors to consider. These include (1) paying attention to strategies and competencies, (2) benchmarking impact and performance, (3) involving management in considering cost, and (4) asking where the market is heading. It is important to consider strategy and competencies. While prioritising the key business processes, management must decide whether or not the areas identified for improvement will be the areas in which core competencies and competitive advantage can be achieved. Benchmarking impact and performance can also help when prioritising business processes. It is important for the company to understand the impact and performance of its processes in relation to those of its competitors. The third factor that Gustafsson and Johnson [7] suggest is cost, which must be taken into account when prioritising processes. In this case managers must consider the relative costs associated with making improvements when deciding which processes to 
improve. Cost can also be used as a tie-breaker when prioritising two processes with equally low performance and high impact. The last factor to consider is to ask where the market is heading. Something that is currently of low importance may become more important to the customer as the market evolves.

QFD was identified in this section as a tool with which a company can prioritise its business processes according to the impact on customer requirements. According to Gustafsson and Johnson [7], QFD can also be used explicitly to consider cost information when translating the voice of the customer into appropriate business processes. QFD can also be used for benchmarking. According to Chase et al. [4], one of the steps in the QFD procedure is to ask customers to rate the company's products against those of the competitor; this helps the company to understand the performance of their products in relation to others. This can also be true for business processes, where customers can be asked to rate the service they received against that of the competitor. Based on this information, the company will be able to measure the performance of its business processes from a customer perspective, helping it to prioritise these processes according to performance. Using a QFD instead of the tree diagram for this purpose may provide managers with a much simpler and more efficient method. From this it is clear that QFD, if applied correctly, can be very useful in prioritising business processes.

Once all the key business processes have been prioritised, the next step (according to Davenport and Short [5]) would be to measure these processes to fit the needs of the customer. This will be discussed in the next section.

\subsubsection{Measuring business process performance}

As mentioned previously, the BSC can be seen as a performance measurement tool. Consequently it defines several generic measures that can be used to assess the current performance of business processes from a customer perspective. According to Kaplan and Norton [9], these measures typically include customer satisfaction, customer retention, new customer acquisition, customer profitability, and market and account share in targeted segments. By measuring the above, a company will be able to see whether its performance is desirable from a customer perspective. The ultimate goal would be to establish where the company went wrong and where improvement is needed. The terms listed above are not new; they were introduced in section 2.1 above. According to Gustafsson and Johnson [7], these terms form a chain of cause and effect, building on each other so that they cannot be treated separately. Figure 1 shows that customer satisfaction will lead to customer retention, customer acquisition, and even profitability. It is also safe to assume that if customer satisfaction in targeted segments increases, market and account share in those targeted segments will increase. It can thus be argued that companies can improve all these measures by improving the satisfaction of targeted customers. Customer satisfaction can be improved by delivering an exceptional customer experience through improved business processes. Section 3.1.3 described two different tools with which to measure business processes. Both the tree diagram and QFD are helpful in identifying the areas in which to improve business processes. According to Ramaswamy [14], before this can be done, the desired performance level in these areas must be established.

\subsubsection{Measuring the desired performance level}

Before processes can be improved to improve customer experience, it must be determined what customers would like to experience - or, more importantly, what they expect to experience. As mentioned previously, business processes can be seen as all service processes or processes that support production [6]. In 1996 Rohit Ramaswamy [14] wrote a book on the design and management of service processes, in which he highlighted the importance of obtaining the desired performance level of a service process before designing new service processes or improving existing service processes. According to him, the desired standard for a service attribute indicates the customers' expectations for the performance of that attribute. The expectations of customers usually arise from their prior 
experience with similar services, and can be determined with a realistic assessment of their needs. Ramaswamy [14] identified two methods with which to obtain the desired performance level of a service attribute. The first is to obtain quantitative information from the customer through interviews. Although this method is useful in obtaining quantitative answers for some attributes, it is not always accurate. According to Ramaswamy [14], his second method is much more accurate. It involves estimating the desired performance level indirectly by examining the extent to which the performance of similar services in the market satisfies customer needs. For this method QFD can be used to determine the desired performance level through benchmarking. During the development of QFD, customers can be asked to rate the service delivered by the competitors (customer benchmark). The desired performance level can then be estimated by looking at the customer benchmark and the actual performance or technical benchmarks of the competitor. Figure 6 is an example of a QFD with customer benchmarks, as demonstrated by Ramaswamy [14].

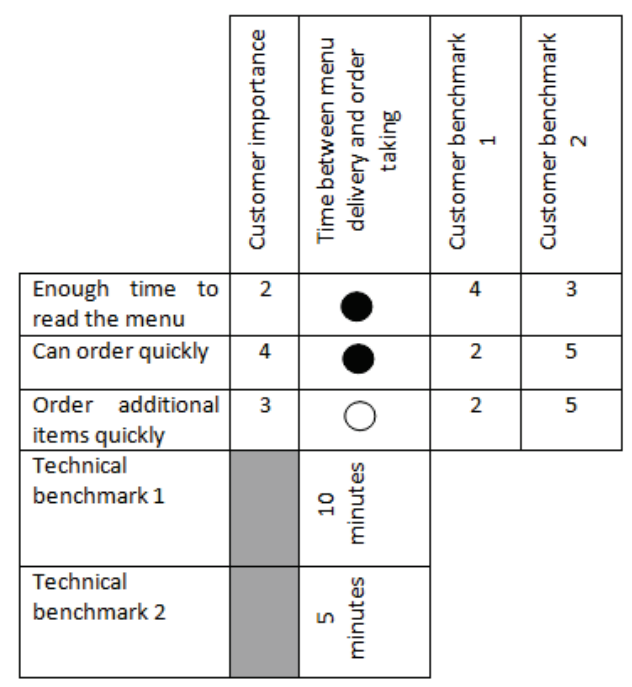

Figure 6: Customer and technical benchmarks (adapted from Ramaswamy [14])

As can be seen from Figure 6, customer needs are better satisfied by competitor 2, who is rated higher on the more important needs. Therefore it is safe to assume that an ordering interval of 5 minutes is closer to customers' desired performance level than competitor 1 's interval of 10 minutes. Although customers may view 5 minutes as an exceptional standard for time between menu delivery and order taking, it may not always be possible to reach or maintain that standard. The difference between the desired standard from a customer perspective and the design standard will depend on the degradation in customer satisfaction that the company is willing to accept. According to Ramaswamy [14], the amount of dissatisfaction arising from the deterioration in performance depends on the relationship between performance and satisfaction. It will not always be possible to perform at the desired performance level. It might be too expensive, or the required technology may be absent, but it is important to determine the maximum deviation from the desired performance level where customer needs will still be satisfied. Once the desired and acceptable performance levels have been determined, business processes must be improved to satisfy this performance level specified by the customer. The next section will discuss various methods with which to improve business processes and to test the improvement initiatives on customer experience. 


\subsubsection{Improving process performance, and testing the impact of these improvements on customer experience}

According to Van Ackere, Larsen, and Morecroft [17], a systems thinking approach is appropriate when improving business processes to fit customer needs. Various techniques offered by systems engineering can be used to model and improve business processes. These techniques include simulation, decision theory, queuing theory, optimisation, utility theory, and others. Gladwin and Tumay [6] argue that analysis and modelling tools can be split into three categories: (1) Flow diagramming tools that help to define processes and workflows by linking text descriptions of processes to symbols; $(2)$ case tools that provide a conceptual framework for modelling hierarchies and process definitions; and (3) simulation modelling tools that provide continuous or discreet-event, dynamic, and stochastic analysis capability. Gladwin and Tumay [6] argue that although 80 percent of re-engineering projects make use of flowcharting tools to determine the current and the to-be state of the business, these tools do not have sufficient capability. Most of these process modelling tools focus on modelling the current state of the business, and lack the ability to predict accurately the outcome of proposed changes to that process. They state that static modelling tools are deterministic and independent of process sequence. These tools are not able to model physical elements of a system such as the layout of the facility or office, and the flow of entities through the facility. According to them, simulation tools are the only tools that provide ways to model entity flow and the dynamic behaviour of business processes. Bhaskar et al. [1] are of the opinion that, if a process contains any random content that is relevant to the re-engineering effort, simulation tools must be employed. They argue that, in contrast to other modelling tools, simulation is well suited to handle the stochastic and time-varying nature of processes, as well as the non-linear interactions between process elements.

A very important aspect that must be considered when improving business processes is to test the impact of these improvement initiatives on customer experience. Bhaskar et al. [1] state that simulation has been able to provide quantitative estimates of the impact that process redesign is likely to have on key performance measures. It can thus be argued that simulation modelling will be the most appropriate tool to use when improving business processes and when testing the impact of these improvements on customer experience. The next section will provide a conceptual model for improving customer experience through improved business processes.

\section{PROPOSED PROCESS IMPROVEMENT MODEL}

As discussed in section 3 of this paper, customer experience and customer satisfaction can be improved through improved business processes, designed to meet the needs of the targeted customer. Thus a model is needed that can help an organisation to improve business processes to fit customer needs. In this paper various methods and techniques have been discussed that can be used to improve customer experience through improved business processes within an organisation. By integrating some of the steps in the 5 step approach proposed by Davenport and Short [5], together with the steps proposed by Camp [3] and Ramaswamy [14], a model for business process improvement can be derived. The various techniques explored in this paper can be used to execute these steps in a simple and efficient manner. This model can be integrated with the process model (Figure 3) suggested by Gustafsson and Johnson [7] to ensure proper alignment between the process improvement initiative and the perspective of the customer. This proposed model is illustrated in Figure 7.

\section{CONCLUSION}

In the 1970s there was a strong focus on the quality of products and services. From this initial focus the orientation moved to a broader view, incorporating the customer's view of quality. According to Ulaga and Chacour [16], the concept of value analysis emerged in the 1950 s when L.D. Miles developed a set of techniques aimed at identifying and removing 
unnecessary cost while still satisfying customer needs. Even then, Miles stated that orientation towards customers' needs and wants should be an integral part of product development. From this it is clear that the focus on customer satisfaction is not a recent phenomenon: it just became more popular through the years, eventually representing the most important goal of any organisation. In today's environment, customer satisfaction is relative to competition. Customers have increasingly more products to choose from and more channels through which they can satisfy their needs. In such an environment it is vital to ensure customer satisfaction, and to maintain this satisfaction through offering quality products and services.

Over the past five decades, many principles and techniques have been designed to help companies take care of frustrated and unhappy customers. Many of these methods have merit and have partly succeeded in increasing customer satisfaction. One of these many techniques is QFD, developed in 1966 with the goal of aligning the voice of the customer with the technical characteristics of products and services. Another technique or methodology is BPR, developed in 1990. Together with benchmarking, BPR aimed to improve business processes in terms of cost, quality, service, and speed. The BSC was developed in 1992 to help companies align their operational activities to their operational strategy. All of these techniques had their useful and valuable traits, as discussed in detail in this paper. These techniques, together with the process model (Figure 3) suggested by Gustafsson and Johnson [7], can be integrated into one comprehensive model that can be used to improve customer experience - and consequently customer satisfaction - through improved business processes.

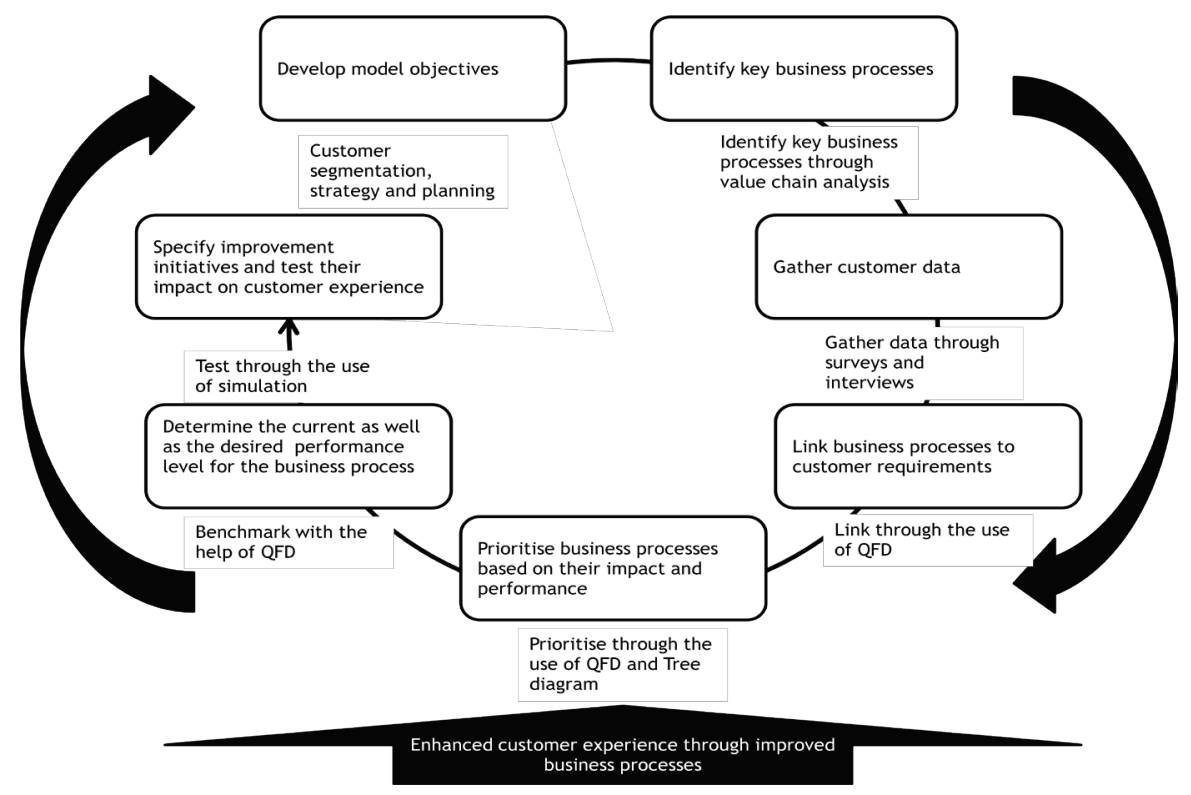

Figure 7: Business process improvement model with integrated customer experience management

This paper defined a step-by-step model for linking the customer experience to business processes and translating the needs of the customer into technical design characteristics for each process. The model may be useful in assisting mangers to satisfy customer needs. By designing business processes to deliver products and services according to the needs of the customer, companies will be able to enjoy the strategic competitive advantage of customer loyalty. 


\section{REFERENCES}

[1] Bhaskar, R. et al., 1994. Analysing and re-engineering business processes using simulation, Proceedings of the 1994 Winter Simulation Conference, 1206-1213.

[2] Blumenthal, A. 2008. User-centric Enterprise Architecture. Available online at http://usercentricea.blogspot.com/2008/04/customer-experience-managementand.html. Retrieved on 2 February 2009.

[3] Camp, R. 1995. Business process benchmarking, ACQC.

[4] Chase, Richard B. et al. 2006. Operations management for competitive advantage with global cases. New York, McGraw-Hill/Irwin.

[5] Davenport, T.H. and Short, J.E. 1990. The new industrial engineering information technology and business process redesign, Sloan Management Review, 11-27.

[6] Gladwin, B., and Tumay, K. 1994. Modeling business processes with simulation tools, Proceedings of the 1994 Winter Simulation Conference, 114-121.

[7] Gustafsson, A. and Johnson, M.D. 2000. Improving customer satisfaction, loyalty, and profit: An integrated measurement and management system, San Francisco, Jossey-Bass Inc.

[8] Hammer, M. 1990. Reengineering work: Don't automate, obliterate, Harvard Business Review, 104-112.

[9] Kaplan, R.S. and Norton, D.P. 1996. Linking the Balanced Scorecard to strategy, California Management Review, Vol. 39, No. 1: 53-79.

[10] Mazur, G. 2008. QFD Institute, The official source for QFD. Available online at http://www.qfdi.org/what_is_qfd/what_is_qfd.htm. Retrieved on 11 February 2009.

[11] Meyer, C. and Schwager, A. 2007. Understanding Customer Experience. Harvard Business Review. February 2007

[12] Payne, A. and Frow, P., 2005. A strategic framework for customer relationship management. Journal of Marketing, Vol. 69, 167-176.

[13] Pidd, M. 1998. Computer simulation in management science. Fourth edition. Wiley.

[14] Ramaswamy, R. 1996. Design and management of service processes: Keeping customers for life. AT\&T.

[15] Schmitt, B. 2003. Customer experience management: a revolutionary approach to connecting with your customers. John Wiley and Sons.

[16] Ulaga, W. and Chacour, S. 2001. Measuring customer perceived value in business markets, a prerequisite for marketing strategy development and implementation. Industrial Marketing Management, Vol. 30, 525-540.

[17] Van Ackere, A., Larsen, E.R., and Morecroft, J.D.W. 1993. Systems thinking and business process redesign: An application to the Beer Game, European Management Journal, Vol. 11: 412-4. 
http://sajie.journals.ac.za 